\title{
6 A Comprehensive Approach to Addressing Gender Equity in STEM Subjects at Four-Year Universities in England
}

\author{
Hyun Kyoung Ro, Frank Fernandez and Benjamin Alcott
}

England has invested to develop a highly qualified and diversified workforce in science, technology, engineering, and mathematics (STEM) fields (Crawford et al., 2011; Smith, 2011). Multiple national initiatives, such as Girls into Science and Technology (GIST) and Women into Science Engineering (WISE), have been implemented to increase women's participation in STEM subjects in England (Smith, 2011; WISE Campaign, 2019, 2020). Despite these national efforts, women are still underrepresented in STEM. Becoming a matter of national concern, politicians have voiced their worries over the economy's overall health and security due to the inadequate number of women in STEM fields (Arnett, 2015). Similarly, the Royal Academy of Engineering argued that U.K. policymakers should improve the underrepresentation of women and minorities and should address its implications on the nation's global competitiveness (Harrison, 2012).

As access to higher education has been expanded in England (Callender, 2006; Greenaway \& Haynes, 2003), women's participation in higher education has increased. Women outperform men on key educational benchmarks. They are more likely to enroll and persist in college than men and they are more likely to obtain degrees and enroll in graduate schools than men in England (Archer et al., 2001; Chowdry et al., 2013; Teachman, 2002). Despite these educational achievements among women, they remain underrepresented in STEM fields (Chowdry et al., 2008; Smith 2011). Women accounted for 16\% of the technology workforce and 10\% of the engineering workforce in 2019 in the United Kingdom (WISE Campaign, 2019). Like other countries in this volume, the United Kingdom is unlikely to address gender inequalities in the labor market without first attending to educational inequalities.

Scholars have argued that women have been kept away from STEM subjects because of systemic and cultural components of STEM disciplines rather than individuals' interests or abilities in post-industrial countries including England (Butz et al., 2006; Gago et al., 2005). Historically, researchers found that women students were underrepresented in STEM fields because of their relatively weak mathematics achievement (e.g., Berryman, 1983). More recently, however, researchers have found that academic achievement in mathematics and science does not appear to account for gender differences in entry into

DOI: $10.4324 / 9781003053217-11$ 
STEM subjects in the United States (Riegle-Crumb et al., 2012; Xie \& Shauman, 2003). Also, scholars claim that there is no gender difference in interest in science subjects at an early age, but the masculine culture in science subjects dissuades women from studying STEM subjects in England (Archer et al., 2017; Kelly, 1985). While studies have documented gender disparities in STEM subjects in England (Smith, 2011), there is still a need for considering more comprehensive ways to promote gender equalities in STEM.

In this chapter we offer a comprehensive overview of women students' pathways to (or away from) studying STEM subjects in England. We include initial childhood intentions to enroll in STEM subjects, prior academic achievement in mathematics subjects (e.g., performance on A-level exams), and enrollment in STEM programs at universities, including prestigious Russell Group universities. We use data from the British Department of Education's Longitudinal Study of Young People in England (also known as Next Steps) to address STEM subject pathways from childhood to higher education. Based on our findings, we seek to provide implications for other post-industrial countries, which face similar challenges in terms of a lack of women in STEM fields. We offer implications on how nations can encourage students, parents, teachers, and faculty to promote women's participation in STEM subjects by considering both K-12 and higher education contexts.

\section{Context and Literature Review}

In this section, we first consider the secondary and postsecondary education context which can shape students' enrollment patterns and subject choices in England. We then focus on class and gender differences in enrollment patterns.

\section{Secondary and Postsecondary Education Context in England}

England has a national school curriculum and a central organization administering applications, making both school examinations and undergraduate admissions processes highly uniform for students across the country. One key feature of this education system is that students begin to specialize in subjects from an early age. During eighth grade, students select 10 subjects - from a range of approximately 30 options - on which they are tested at the end of the tenth grade in examinations known as General Certificates of Secondary Education (henceforth GCSEs). Schooling ceases to be compulsory after these exams; those who do not pass five or more GCSEs - around two-fifths in recent years (House of Commons Education Committee, 2013) - tend either to enter employment or leave the standard high school system, attending further education institutions in order to retake these exams or study vocational courses. Thus, students hoping to progress beyond the compulsory stages of education are required to choose appropriate GCSE subjects at the end of eighth grade and perform well in those subjects at the end of tenth grade. GCSEs provide a strong predictor of future university attendance (Chowdry et 
al., 2013), operating as a "symbolic and material currency in terms of future educational progression" (Davey \& Fuller, 2013, p. 3.1).

Students that pass at least five GCSEs are able to continue to the final two years of high school to take Advanced Levels exams (henceforth A-levels). Students choose three or four A-level subjects, can only study those for which they took GCSEs, and must select certain ones in order to study a particular discipline at the university. For example, students hoping to study medicine at the university need to take extended-science GCSEs as well as mathematics and biology at A-level. In their university applications, students must specify which discipline they plan to study. Students do not take introductory classes across a range of subjects during their degree programs; instead, they only study courses in either a single- or dual-subject program from the outset.

All undergraduate applications are managed by a single organization: the Universities and Colleges Admissions Service (henceforth UCAS). The application process is largely uniform across institutions: universities have access to candidates' personal statements, anticipated A-level results (as predicted by schoolteachers), and GCSE results. Only a minority of institutions use interviews to further screen applicants. UCAS has been in place for 20 years, GCSE exams for 28 years, and A-levels for over 60 years. For two decades, then, the undergraduate admissions process for English universities has followed a consistent pattern with a uniform process. The system is clear, but it requires students to envisage coherent academic trajectories and perform well in examinations from mid-adolescence.

\section{Prestigious Universities in England}

England has internationally recognized, prestigious universities in its higher education system (Shanghai Ranking Consultancy, 2014; Times Higher Education, 2015; U.S. News and World Reports, 2015). The Russell Group is one common means of classifying university prestige in England. While not an objective signifier of university quality, 22 of the 24 Russell Group universities are ranked among the top 30 U.K. universities in the Times' (2015) league tables. And, four are in the top 10 universities in the world, 15 are in the top 100, and all 24 members of the Russell Group are ranked among the top 250 universities in the world according to the 2018 QS World University Rankings (The Russell Group of Universities, n.d.).

Students' social class is one of the factors that allow (or prevent) access to Russell Group universities. Researchers found that low-socioeconomic status (low-SES) applicants are less likely both to apply and be admitted to Russell Group universities (Boliver, 2015; Reay et al., 2010). Ethnic minority students also were less likely to be admitted to Russell Group universities, even after accounting for the academic subject or program to which they applied (Boliver, 2013, 2016; Hemsley-Brown, 2015). Access to the Russell Group may in turn reinforce class and ethnic disparities, given that graduates of Russell Group universities are more likely to earn high salaries than students from 
other universities in England (Chevalier \& Conlon, 2002). Researchers have suggested that more studies examine how both family backgrounds and primary or secondary education influence students' readiness and access to study STEM subjects (Engberg \& Wolniak, 2013; Nunes et al., 2017; Ro et al., 2018) at prestigious universities or non-prestigious universities (Reay, 1998; Vincent et al., 2008; Walker \& Clark, 2010). However, few studies examine how the relationship between STEM subject choice and the selectivity of institution admission varies by gender.

\section{Class Disparities in University Enrollment}

Although student enrollment at higher education institutions in the United Kingdom has slowed down since 2000 (Bolton, 2020), the provision of university education has increased precipitously over the past half century. The number of universities tripled between 1960 and 2000; around 20 institutions were built in the 1960s, and 35 polytechnics were re-accredited as universities in 1992 (Greenaway \& Haynes, 2003). This growth in supply has been accompanied by a commensurate growth in demand. In 2000, student enrollment in the United Kingdom stood at 2 million, representing a fivefold increase since the 1960s (Greenaway \& Haynes, 2003). The proportion of citizens aged 18-22 who were enrolled at a university rose from 5\% in 1960 to $17 \%$ in 1990 and then to $33 \%$ in 2000 (Callender, 2006).

The long-term growth in application numbers should not mask that participation in higher education is highly stratified (Anders, 2012; Archer et al., 2003; Ball, 2008). To date, researchers in England have considered various dimensions of disparity. Enrollment rates have not been shown to differ substantially by region and distance from a university (Gibbons \& Vignoles, 2012), although they do differ greatly according to neighborhood deprivation and parental income (Singleton, 2010; Vignoles \& Powdthavee, 2009). Between the 1960s and 1980s, academic achievement became less predictive and social class more predictive of university applications (Machin \& Vignoles, 2004), a trend that continued into the 1990s (Blanden \& Machin, 2004; Galindo-Rueda et al., 2008; Glennerster, 2002). By 2009, students from the most advantaged quintile of households were six times more likely to attend university than those from the least advantaged quintile (Vignoles \& Powdthavee, 2009).

\section{Factors Shaping Gender Disparities in STEM Subjects at Prestigious Universities}

While men are consistently less likely to enroll in an undergraduate course than women (Archer et al., 2001; Chowdry et al., 2013), women are less likely to study STEM subjects than men (Smith, 2011). The first factor that affects gender disparities in STEM subject choice, particularly at prestigious universities, is students' social class. Class-based educational inequality of access to prestigious universities has been extensively documented (for example, Anders, 2012; Ball 
et al., 2002; Boliver et al., 2017; Gorard et al., 2006; Reay, 1998), yet there is a lack of research focusing on gender gaps in the intersection between subject choice and institutional prestige. Disparities in social class can be reinforced over time as richer students tend to gain more access to prestigious universities (Boliver, 2011; Hussein, McNally, \& Telhaj, 2009).

Subject choice also plays a role: students who earn degrees in STEM fields tend to have higher earnings than those in social science and humanities fields (Chevalier, 2011; Walker \& Zhu, 2011). In turn, the income benefits of STEM degrees can strengthen the selectivity of institutions. Using the National Longitudinal Survey of Youth in the United States, Davies and Guppy (1997) examine processes by which students enter lucrative fields of study, selective colleges, and lucrative fields within selective colleges. They classify, according to mean monthly income, 15 fields of study as "lucrative." They find that students' SES does not relate to access to lucrative fields after controlling for other background factors. However, SES predicts enrollment in selective colleges and lucrative fields within selective colleges. Few studies have addressed the intersection between enrollment at prestigious institutions and major choice by gender. One exception is Ro et al. (2018), who found that women students are less likely to study STEM subjects when they study at prestigious universities in England. Thus, it is critical to have more studies that examine the drivers of socioeconomic disparities between men and women in the intersection between STEM subject choice and prestigious institutional enrollment.

The second factor that researchers have examined in relation to access to postsecondary education is students' prior curricular exposure and academic achievement. Achievement differences tend to broaden throughout pre-elementary, elementary, and secondary education and it may be too late by secondary school to address university readiness gaps (Blanden \& Machin, 2004; Feinstein, 2003; Heckman \& Lochner, 2000; Jerrim \& Vignoles, 2013). However, previous studies of subject choice and university enrollment examined achievement gaps, especially in mathematics and science proficiency, at the secondary school level without addressing achievement at earlier educational stages. College admissions tests may overlook the cumulative effect of early-stage academic achievement and secondary educational curricula on university enrollment and subject selection (ACT, 2010; Zwick, 2006). More studies are needed to examine how students' earlier curricular experiences and achievement shapes their subject choice at a university, which may differ by gender.

The third factor is the culture or context of STEM disciplines rather than students' individual attributes. Researchers have raised the issue that secondary educational curricula and teachers' pedagogies and attitudes tend not to relate to the interests and values of women (Calabrese et al., 2008; Tan et al., 2013). Scholars argue that both men and women students express interest in science subjects, but women tend to receive less encouragement and resources from teachers and families to study science, particularly physical sciences, after their compulsory education (Archer, 2017; Mujtaba \& Reiss, 2013). 
Despite interest and aspiration to become scientists and engineers among women, the masculine culture of science, physics, and engineering fields dissuades women from continuing to pursue STEM subjects (Danielsson, 2012: Faulkner, 2007). Still, some women successfully navigate the masculine culture of STEM subjects, and this happens when women have a higher level of social class. Interviewing seven students from age 10 to 16 who aspired to continue with physics post-16 years of age, Archer et al. (2017) described their study findings of

structural and social class inequalities and the cultural arbitrary of physics not only potentially puts off girls (because they do not offer an attractive and/or achievable vision of who girls can be within these subject areas) but also may actively work against and prevent some girls ... from continuing, even when they want to. (p. 118)

Although we do not measure the culture of STEM disciplines in the analysis, we discuss our findings in the context of STEM disciplines, particularly at prestigious universities.

\section{Methods}

Informed by prior literature, we set out to examine individual and structural factors that may influence gender equity in U.K. STEM higher education. In particular, we described the gender difference in plans to study STEM subjects around age 17 to measure whether interests or plans vary by gender. We also present the gender difference in academic preparedness in terms of mathematics test scores at year 5 or 6 of primary school and later university preparatory curricular experiences which affect STEM subject choices and university enrollment. We then examined whether women had lower odds of enrolling in STEM higher education after accounting for family background and academic performance. Additionally, because prior literature suggests that Russell Group universities have exclusionary admissions practices, we tested whether access to STEM higher education by gender was stratified by university prestige.

To begin, given that we seek to offer implications from our study to other post-industrial countries, we checked how representative U.K. higher education is - in terms of enrollments by subject and gender - compared to the European Union (EU). We downloaded data from the European Institute for Gender Equality's Gender Statistics Database (GSD). The database includes information on the relative distribution of students enrolled in higher education by student gender and academic subject. GSD uses broad fields of study, so we classified "Agriculture, forestry, fisheries and veterinary," "Engineering, manufacturing and construction," "Information and Communication Technologies" and "Natural sciences, mathematics and statistics" as STEM subjects; all other fields were coded as non-STEM subjects. We found that the United Kingdom 
is relatively similar to the average for EU countries in both percentages of students studying STEM and non-STEM subjects and the gender split within STEM and non-STEM subjects. See Figure 6.1.

Although the structure of schooling varies throughout the EU, the U.K. case appears to represent a common challenge of gender inequality in STEM throughout Europe. We recognize that our findings are not generalizable to other countries in the EU. However, we hope that this chapter may provide some insights for other countries that may aspire to increase the percentage of students studying STEM subjects, as well as increase the percentage of women in STEM higher education.

\section{Data}

We analyze data from the British Department of Education's Longitudinal Study of Young People in England (LSYPE) data set (now extended as the Next Steps study) to examine gender equality in STEM higher education in the United Kingdom. LSYPE included seven waves of data collection from 2004 to 2010. The survey includes historical background (demographic) information, parental and family background data, measures of academic performance, and enrollment outcomes. For more information about sampling procedures and the structure of the LSYPE data set, as well as for examples of how LSYPE has been previously used to examine access to STEM higher education, see Alcott (2017) and Ro et al. (2018). Subjects were coded differently in LSYPE than in GSD (used for Figure 6.1). For our analysis of LSYPE data, we coded majors into mutually-exclusive STEM and non-STEM categories. We included biological sciences, physical sciences, mathematics, computer sciences, engineering, or technology-based academic programs as STEM subjects and all other subjects as non-STEM subjects (see Chen \& Weko, 2009).

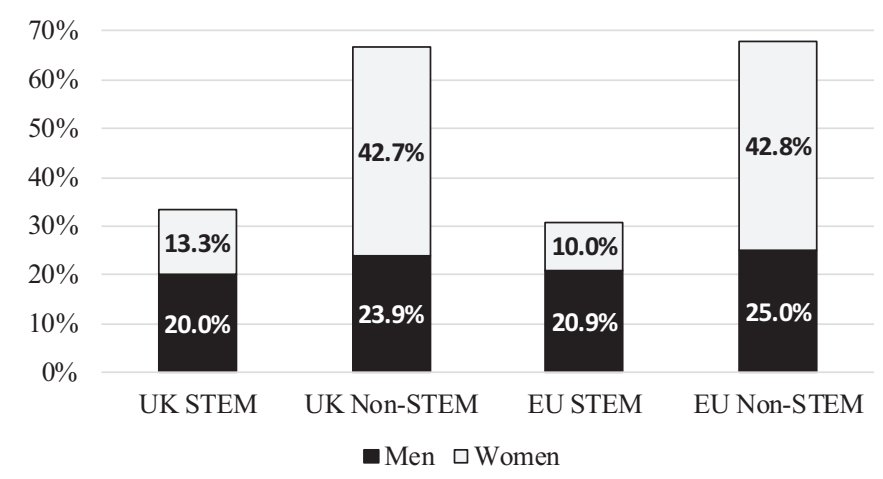

Figure 6.1 Percentages of men and women by STEM and non-STEM enrollment in the United Kingdom and EU. 


\section{Analytic Approach}

For this chapter, we started by examining gender differences in intention to study STEM at age 17 using a chi-square test. We also tested gender differences in academic preparedness (taking multiple A-levels in STEM fields) using a chi-square test, and we examined prior achievement using Wald tests to check whether mean differences in achievement between men and women were statistically significant.

To measure the gender differences by STEM subject choice and university enrollment by the level of institutional prestige, we examined data for LSYPE participants who enrolled at any type of university in any subject. As an analytical approach, we estimated logistic regression models for each outcome. We first examined whether women had lower odds than men of studying STEM at any university. Then, we considered whether women had lower odds compared to men of studying STEM at a Russell Group university. In our analyses, we controlled for students' social class background (i.e., whether their parents had a university degree and the relative income levels of their home neighborhoods using the British government's Income Deprivation Affecting Children Index scores) and their academic background, including early mathematics proficiency and secondary school preparation for university (including passing A-levels and taking science courses). We used the survey's sampling weights in our analyses. To account for missing data, we used a listwise deletion approach when there were missing values in the variables of interest. We did not use imputation procedures because analyses with listwise deletion have approximately unbiased estimates even when data are not missing at random (Little, 1992). We calculated inverse odds ratios by exponentiating odds ratios less than 1 for ease of interpretation (DesJardins, 2001).

\section{Findings}

We could not explain the gender disparity in STEM higher education through differences in STEM intentions. Results from Pearson's chi-squared test show that, compared to men, a statistically significant higher percentage of women intend to study STEM at age 17 ( $\mathrm{p}<0.05)$. Substantively, the difference in percentages was small $(8.3 \%$ of women compared to $7.9 \%$ of men), but it confirms that women's underrepresentation in STEM is likely not attributable to differences in interest or intention.

In terms of prior academic achievement, we first examined the bivariate relationship between gender and mathematics preparedness in primary school (year 5 or 6). A Wald test confirmed that girls scored lower, on average, than boys by approximately 18 points on Key Stage 2 mathematics tests $(\mathrm{p}<0.05)$. Prior to university enrollment, $16.9 \%$ of men took the more advanced science course offered during GCSEs (commonly known as "triple science," in contrast to the standard "double science") compared to $14.6 \%$ of women ( $p<0.001)$, however, women scored higher on A-level exams than men $(p<0.05)$. 
After our bivariate analyses of multiple indicators along the primary and secondary school pathway to studying STEM in higher education, we tested multivariate relationships among students' backgrounds and experiences and higher education enrollment. Compared to men, women had lower odds of studying STEM subjects at any university. Holding social class and academic background variables constant, men had approximately 60\% higher odds of studying STEM than women. Similarly, women had lower odds of studying STEM at the subgroup of Russell Group universities; men had 68\% higher odds of studying STEM at a Russell Group university than women. In our model that estimated odds of studying STEM at any university, we found that early mathematics performance was statistically related to enrollment in a STEM subject. However, for studying STEM at a Russell Group university, we found that social class mattered whereas early mathematics scores did not. Students whose parents had a university degree had 77\% higher odds of studying STEM within the Russell Group compared to students who were the first in their family to attend university.

We specified a third model to test whether women faced similarly long odds in attending Russell Group universities when we did not limit the sample to STEM students. Among students in all subjects, we found that women did not have statistically significantly different odds than men in attending Russell Group universities. In other words, the "penalty" for women in attending Russell Group universities appeared to be limited to enrollment in STEM fields. See Table 6.1.

Table 6.1 Women's Odds of Studying STEM or Attending Russell Group Universities: Data from Longitudinal Study of Young People in England (LSYPE)

\begin{tabular}{|c|c|c|c|c|c|c|c|}
\hline \multirow[b]{3}{*}{ Woman } & \multicolumn{3}{|c|}{$\begin{array}{l}\text { Studied STEM at any } \\
\text { university }(\mathcal{N}=3,940)\end{array}$} & \multicolumn{2}{|c|}{$\begin{array}{l}\text { Attended Russell Group to } \\
\text { study STEM }(\mathcal{N}=1,050)\end{array}$} & \multicolumn{2}{|c|}{$\begin{array}{l}\text { Attended Russell } \\
\text { Group to study any } \\
\text { subject }(2,890)\end{array}$} \\
\hline & \multicolumn{2}{|c|}{ Odds ratio } & \multirow{2}{*}{$\begin{array}{l}\text { Std. } \\
\text { err. } \\
0.04\end{array}$} & Odds ratio & \multirow{2}{*}{$\begin{array}{l}\text { Std. err. } \\
0.11\end{array}$} & \multirow{2}{*}{$\begin{array}{l}\text { Odds } \\
\text { ratio } \\
1.08\end{array}$} & \multirow{2}{*}{$\begin{array}{l}\text { Std. } \\
\text { err. } \\
0.14\end{array}$} \\
\hline & 0.47 & $* * *$ & & $0.52 * *$ & & & \\
\hline $\begin{array}{l}\text { Triple science } \\
\text { GCSEs }\end{array}$ & 1.17 & & 0.11 & 0.99 & 0.18 & 1.02 & 0.16 \\
\hline Passed A-levels & 1.04 & $* *$ & 0.02 & 1.38 *** & 0.05 & 1.38 *** & 0.03 \\
\hline $\begin{array}{l}\text { Math Score at } \\
\text { Year } 5\end{array}$ & 1.52 & $* * *$ & 0.13 & 1.30 & 0.27 & 1.07 & 0.14 \\
\hline $\begin{array}{l}\text { Parent without } \\
\text { university } \\
\text { degree }\end{array}$ & 1.17 & & 0.12 & $0.57 \quad * *$ & 0.10 & 0.49 *** & 0.08 \\
\hline $\begin{array}{l}\text { Neighborhood } \\
\text { Poverty } \\
\text { (IDACI score) }\end{array}$ & 0.93 & & 0.05 & 0.86 & 0.11 & 0.95 & 0.08 \\
\hline Constant & 0.05 & $* * *$ & 0.02 & $0.03 * * *$ & 0.03 & $0.06 * * *$ & 0.03 \\
\hline
\end{tabular}




\section{Hyun Kyoung Ro et al.}

Our findings come with several limitations. First, we were not able to examine application data to account for self-selection effects. In other words, we did not know whether women applied to study STEM subjects at Russell Group universities and were denied admission or whether they only applied to universities outside the Russell Group. Second, conditional on admission, we were not able to account for factors that may have influenced students' decisions about where to enroll in college (e.g., distance to home, differences in costs of attendance). Third, we did not include early aspirations or intentions to study STEM because that variable in LSYPE was missing so many values that the sample sizes would have been drastically reduced in our analyses.

\section{Discussion and Implications}

Just like other post-industrial countries, England has invested to increase more women in STEM education and ultimately the STEM workforce. Increasing the participation of women in STEM promotes advancements in science, research, and technology, which enhances a nation's economic prosperity and societal well-being (Blair, 2006; Brennan \& Naidoo, 2008). Increasing women in STEM fields can also disrupt gender disparities in income, given that STEM fields usually offer higher earnings (Chevalier, 2011; Walker \& Zhu, 2011). Policy makers and scholars have emphasized increasing women's participation in STEM as a national priority for gender equity and economic development in England. While men are consistently less likely to enroll in an undergraduate course than women (Archer et al., 2001; Chowdry et al., 2013), women students are still less likely to study STEM subjects than men students (Smith, 2011). By revising literature from both secondary and postsecondary education and using a nationally representative, longitudinal study in England, we discuss several main findings with existing literature along with future research inquires and policy and practice implications.

Early mathematics achievement at year 5 and 6 differs by gender: women had lower scores than men. However, women performed better on A-level examinations than men. When we measured students' intention to study STEM subjects at universities by age 17, a greater number of women students actually expressed an intention to study STEM subjects than men. This finding is important because the lower level of STEM enrollment among women may not be attributable to lack of interest in studying STEM subjects. Educational aspiration or intention in general is directly and positively related to their actual enrollment in higher education (Hu, 2003), which we found was positively related to STEM enrolment in the regression analyses after controlling for gender. Building on the work of Archer et al. (2017), further qualitative inquiry is needed to explore the reasons for the disconnect between intention to study STEM subjects and actual subject choice among women in this study. Faculty and staff may interact with secondary school students who have intentions to study STEM subjects but who ultimately do not enroll in STEM. Teachers and school counselors may consider how to encourage 
women students who intend to study STEM subjects, to enroll in more STEM GCSEs, and to prepare to attend university.

It may not be surprising that we found women have lower odds of studying STEM subjects at any university and at Russell Group universities. It is interesting that the odds of studying any subject (i.e., both STEM and nonSTEM subjects) at Russell Group universities do not differ by gender. From our study, it is uncertain whether women do not "choose" to attend Russell Group universities when they study STEM subjects, or whether the prestigious universities have more preference for men students when admitting students to study STEM subjects. U.S. scholars have claimed that selective institutions have more male-preference admission processes (Bielby et al., 2014). However, U.S. researchers did not examine how the intersection between STEM disciplines and selective institutions encourages or prevents universities from accepting more women. This is a key question for future inquiry, given that educational degrees in STEM subjects, and from more prestigious institutions, help students secure high paying careers, social mobility, and leadership positions. More studies need to look at the admission and persistence, learning and engagement, and sense of belonging among women in STEM subjects at prestigious institutions.

We also offer new research ideas to examine the diverse backgrounds of women students who choose STEM subjects at different types of institutions. Although there are benefits to examining data from a nationwide and longitudinal study, we could not analyze the interaction effects between women and other background measures (e.g., parental education, social class) due to the small sample size. We found that students who have parents with university degrees are more likely to study at Russell Group universities and the effect of parental education on students' STEM subject choice at prestigious universities may differ by gender.

Parents can play a key role in en(dis)couraging their children to study STEM subjects. In addition to parental education, parental occupations may relate to students' STEM subject choice. Archer et al. (2017) found that girls who persist in physics subjects possess high levels of not only family capital, but more specifically science-oriented family habitus and cultural and social capital. Parents who work in elite or middle-class STEM fields may recognize the strategic potential for their children's major choice. Bengtsson's (1983) study of Swedish women university students found that a larger proportion of women studying natural sciences had fathers who studied or worked in the same field. While parents in non-science fields may underestimate their daughters' attraction to science books, parents in STEM fields may encourage their daughters to experience more science literacy. Parents with a high-level of economic capital and science-based social and cultural capital tend to help their daughters continue in the track of STEM subjects, despite the unwelcoming culture of STEM disciplines (Archer et al., 2017).

Human capital theory may explain the lower level of women's participation in STEM subjects at prestigious universities. According to human capital 
theory, students decide where and what to study on the basis of anticipated future earnings. Becker (1965, 1976) claimed that students operate according to the "well-known equilibrium condition" (1976, p. 123) that they should pursue additional higher education until the point where present costs outweigh expected future returns. Becker (1980) argued that parents may not only extend funds to help students attend costly universities, they may also help students think through the equilibrium condition - thereby influencing students' willingness to take financial risks and incur higher short-term university costs with the expectations of greater future earnings. While women were less likely to take degrees in STEM subjects (Chowdry et al., 2008; Smith, 2011), future returns may influence women students' decision for where they study when they choose to study STEM subjects (Ro et al., 2018). Future research should examine whether women students may not choose STEM subjects, particularly at prestigious universities, because women experience relatively lower income premiums from their college degrees and endeavor not to lose as much in foregone earnings as men.

We also offer policy and practice implications, which can be applicable in other post-industrial countries. For example, although educational systems in the United Kingdom and other post-industrial countries including the United States are substantially different, there are common challenges for improving gender equity in both countries. We argue that in post-industrial countries policymakers and teachers should consider supporting gender equity through early achievement in mathematics, secondary school course taking, and the importance of standardized university admissions tests. For example, the chapter on Germany in this volume by Dusdal and Fernandez also illustrates that women had interest in studying engineering but were deterred because they did not complete pre-requisite courses. Despite interest or intentions to study STEM, testing and course taking create opportunities to reinforce gender stereotyping or to allow gender stereotypes to manifest themselves in the pathway to STEM higher education.

\section{Conclusion}

In this chapter we offer a comprehensive overview of women students' pathways to (or away from) studying STEM subjects, including initial intentions to enroll in STEM subjects, prior academic achievement in mathematics and science, and actual enrollment in STEM programs at universities, including prestigious Russell Group universities, in England. We use a nationally representative, longitudinal data set to address STEM subject pathways by gender. While we found that women students express their intention to study STEM subjects at universities just like men, women students' actual enrollment is lower than men's in STEM subjects. Furthermore, women students are less likely to enroll to study STEM subjects at Russell Group universities than men, even though there was no difference in Russell Group universities by gender when we do not consider subjects. Further studies need to explore whether women do not 
choose prestigious universities when they apply to study STEM subjects or prestigious universities have male-preferences in admissions when they select students in STEM subjects. We also encourage scholars and practitioners to consider cultural contexts for both STEM disciplines and institutions rather than focusing solely on individual students' attributes, such as their intention to study STEM subjects or their academic achievement.

\section{References}

ACT. (2010). College readiness. http://files.eric.ed.gov/fulltext/ED510475.pdf

Alcott, B. (2017). Does teacher encouragement influence students' educational progress? A propensity-score matching analysis. Research in Higher Education, 58(7), 773-804.

Anders, J. (2012). The link between household income, university applications and university attendance. Fiscal Studies, 33(2), 185-210.

Andre, T., Whigham, M., Hendrickson, A., \& Chambers, S. (1999). Competency beliefs, positive affect, and gender stereotypes of elementary students and their parents about science versus other school subjects. Fournal of Research in Science Teaching, 36, 719-747.

Archer, L., Hutchings, M., \& Ross, A. (2003). Higher education and social class: Issues of exclusion and inclusion. Routledge Falmer.

Archer, L., Moote, J., Francis, B., DeWitt, J., \& Yeomans, L. (2017). The "exceptional" physics girl: A sociological analysis of multimethod data from young women aged 10-16 to explore gendered patterns of post-16 participation. American Educational Research Fournal, 54(1), 88-126.

Archer, L., Pratt, S. D., \& Phillips, D. (2001). Working-class men's constructions of masculinity and negotiations of (non) participation in higher education. Gender and Education, 13(4), 431-449.

Arnett, D. K. (2015). Plugging the leaking pipeline: Why men have a stake in the recruitment and retention of women in cardiovascular medicine and research. Circulation: Cardiovascular Quality and Outcomes, 8(2_suppl_1), S63-S64.

Ball, S. J. (2008). The education debate: Policy and politics in the twenty-first century. The Policy Press.

Ball, S. J., Davies, J., David, M., \& Reay, D. (2002). 'Classification' and 'judgement': Social class and the 'cognitive structures' of choice of higher education. British Journal of Sociology of Education, 23(1), 51-72.

Becker, G. S. (1965). A theory of the allocation of time. The Economic Fournal, 75(299), 493-517.

Becker, G. S. (1976). The economic approach to human behavior. The University of Chicago Press.

Becker, G. S. (1980). Human capital: A theoretical and empirical analysis, with special reference to education (2nd ed.). The University of Chicago Press.

Bengtsson, M. 1983Foraldraidentifikation hos ksinnliga naturvetare och humanister- utsecklingspsyhologiska, differentiella och socialpsyhologiska aspekter [Parental identification on the part of women studying natural sciences or the arts - Develop- mental, differential and social psychological aspects] [Doctoral dissertation, Lund University].

Berryman, S. E. (1983). Who will do science? Trends, and their causes, in minority and female representation among holders of advanced degrees in science and mathematics. Rockefeller Foundation. 
Bielby, R., Posselt, J. R., Jaquette, O., \& Bastedo, M. N. (2014). Why are women underrepresented in elite colleges and universities? A non-linear decomposition analysis. Research in Higher Education, 55(8), 735-760.

Blair, T. (2006, November 3) Our nation's future: Science. [Speech transcript]. https:// webarchive.nationalarchives.gov.uk/+/http://www.number10.gov.uk/Page 10342

Blanden, J., \& Machin, S. (2004). Educational inequality and the expansion of UK higher education. Scottish Fournal of Political Economy, 51(2), 230-249.

Boliver, V. (2011). Expansion, differentiation, and the persistence of social class inequalities in British higher education. Higher Education, 61, 229-242.

Boliver, V. (2013). How fair is access to more prestigious UK universities? The British Journal of Sociology, 64, 344-364.

Boliver, V. (2015). Lies, damned lies, and statistics on widening access to Russell Group universities. Radical Statistics, 113, 29-38.

Boliver, V. (2016). Exploring ethnic inequalities in admission to Russell Group universities. Sociology, 50, 247-266.

Boliver, V., Gorard, S., \& Siddiqui, N. (2017). How can we widen participation in higher education? The promise of contextualised admissions. In R. Deem \& H. Eggins (Eds.), The university as a critical institution? (pp. 95-109). Sense Publishers.

Bolton, P. (2020, October 21). Higher education student numbers. UK Parliament. https:// commonslibrary.parliament.uk/research-briefings/cbp-7857/

Brennan, J., \& Naidoo, R. (2008). Higher education and the achievement (and/or prevention) of equity and social justice, Higher Education, 56, 287-302.

Butz, W. P., Bloom, G. A., Gross, M. E., Kelly, T. K., Kofner, A., \& Rippen, H. E. (2006). Is there a shortage of scientists and engineers? How would we know? [Issue Paper]. RAND Corporation. https://rand.org/pubs/issue_papers/IP241.html

Calabrese Barton, A., Tan, E., \& Rivet, A. (2008). Creating hybrid spaces for engaging school science among urban middle school girls. American Educational Research fournal, 45(1), 68-103.

Callender, C. (2006). Access to higher education in Britain: The impact of tuition fees and financial assistance. In P. N. Teixeira, D. B. Johnstone, M. J. Rosa, and H. Vossensteyn (Eds.), Cost-sharing and accessibility in higher education: A fairer deal? (pp. 105-132). Springer.

Carneiro, P., \& Heckman, J. J. (2002). The evidence on credit constraints in post-secondary schooling. The Economic Fournal, 112(482), 705-734.

Carneiro, P. and Heckman, J. J. (2003). Human capital policy. In J. J. Heckman, A. Krueger, \& B. Friedman (Eds.), Inequality in America: What role for human capital policies? (77-239). The MIT Press.

Chen, X., \& Weko, T. (2009). Students who study science, technology, engineering, and mathematics (STEM) in postsecondary education, (Report No. 2009-2161). National Center for Educational Statistics.

Chevalier, A. (2011). Subject choice and earnings of UK graduates. Economics of Education Review, 30(6), 1187-1201.

Chevalier, A., \& Conlon, G. (2002). Variations in the returns to university degree in the UK, a Cohort Analysis [Mimeo]. University College Dublin.

Chowdry, H., Crawford, C., Dearden, L., Goodman, A., \& Vignoles, A. (2008). Understanding the determinants of participation in higher education and the quality of institute attended: Analysis using administrative data. https://www.ifs.org.uk/publications/4279

Chowdry, H., Crawford, C., Dearden, L., Goodman, A., \& Vignoles, A. (2013). Widening participation in higher education: Analysis using linked administrative data. Journal of the Royal Statistical Society: Series A (Statistics in Society), 176(2), 431-457. 
Crawford, C., Johnson, P., Machin, S., \& Vignoles, A. (2011). Social mobility: A literature review. Department for Business, Innovation and Skills. https://assets.publishing.ser vice.gov.uk/government/uploads/system/uploads/attachment_data/file/32111/ 11-750-social-mobility-literature-review.pdf

Danielsson, A. T. (2012). Exploring woman university physics students "doing gender" and "doing physics." Gender and Education, 24(1), 25-39.

Davey, G., \& Fuller, A. (2013). Hybrid qualifications, institutional expectations and youth transitions: A case of swimming with or against the tide. Sociological Research Online, 18(1), 200-209. https://doi.org/10.5153/sro.2876

Davies, S., \& Guppy, N. (1997). Fields of study, college selectivity, and student inequalities in higher education. Social Forces, 75, 1417-1438.

DesJardins, S. L. (2001). A comment on interpreting odds-ratios when logistic regression coefficients are negative. AIR Professional File, 81(1), 1-7.

Dryler, H. (1998). Parental role models, gender and educational choice. British Fournal of Sociology, 375-398.

Engberg, M., \& Wolniak, G. G. (2013). College student pathways to the STEM disciplines. Teachers College Record, 115(1), 1-27.

Faulkner, W. (2007). 'Nuts and bolts and people': Gender-troubled engineering identities. Social Studies of Science, 37(3), 331-356.

Feinstein, L. (2003). Inequality in the early cognitive development of British children in the 1970 cohort. Economica, 70, 73-97.

Gago, J. M., Ziman, J., Caro, P., Constantinou, C. P., Davies, G., Parchmann, I., Rannikmae, M., \& Sjoberg, S. (2005). Europe needs more scientists: Report by the high level group on increasing human resources for science and technology. Office for Official Publications of the European Communities.

Galindo-Rueda, F., Marcenaro-Gutiérrez, O., \& Vignoles, A. (2008). The widening socioeconomic gap in UK higher education. In S. Gorard (Ed.), Quantitative research in education (Vol. 1, pp. 75-88). Sage.

Gibbons, S., \& Vignoles, A. (2012). Geography, choice and participation in higher education in England. Regional Science and Urban Economics, 42(1), 98-113.

Glennerster, H. (2002). United Kingdom education 1997-2001. Oxford Review of Economic Policy, 18(2), 120-136.

Glover, J., \& Fielding, J. (1999). Women and the sciences in Britain: Getting in? Fournal of Education and Work, 12(1), 57-73.

Gorard, S., Smith, E., May, H., Thomas, L., Adnett, N., \& Slack, K. (2006, July). Review of widening participation research: Addressing the barriers to participation in higher education. Higher Academy and the Institute for Access Studies. Higher Education Funding Council for England.

Grauca, J. M., Ethington, C. A., \& Pascarella, E. T. (1988). Intergenerational effects of college graduation on career sex atypicality in women. Research in Higher Education, 29(2), 99-124.

Greenaway, D., \& Haynes, M. (2003). Funding higher education in the UK: The role of fees and loans. The Economic Fournal, 113(485), F150-F166.

Harrison, M. (2012, September). Fobs and growth: The importance of engineering skills to the UK economy: Royal Academy of Engineering Econometrics of Engineering Skills Project. Royal Academy of Engineering. https://www.raeng.org.uk/publications/reports/jobs-a nd-growth

Heckman, J. J., \& Lochner, L. (2000). Rethinking education and training policy: Understanding the sources of skill formation in a modern economy. In S. Danziger 
\& J. Waldfogel (Eds.), Securing the future: Investing in children from birth to college (pp. 4783). Russell Sage Foundation.

Hemsley-Brown, J. (2015). Getting into a Russell Group university: High scores and private schooling. British Educational Research Fournal, 41, 398-422.

Hetherington, E. M. (1965). A developmental study of the effects of sex of the dominant parent on sex-role preference, identification, and imitation in children. Fournal of Personality and Social Psychology, 2(2), 188.

House of Commons Education Committee. (2013). From GCSEs to EBCs: The government's proposals for reform. London: The Stationery Office. https://www.parliament.uk/docum ents/commons-committees/Education/EIGHTH-REPORT-GCSEs-to-ECBs-Reform -HC-808.pdf

$\mathrm{Hu}$, S. (2003). Educational aspirations and postsecondary access and choice. Education Policy Analysis Archives, 11, 14.

Hussein, I., McNally, S., \& Telhaj, S. (2009). University quality and graduate wages in the UK (Paper No. 4043). Institute for the Study of Labor. ttps://www.econstor.eu/bit stream/10419/35561/1/59516773X.pdf

Jerrim, J., \& Vignoles, A. (2013). Social mobility, regression to the mean and the cognitive development of high ability children from disadvantaged homes. Fournal of the Royal Statistical Society: Series A (Statistics in Society), 176, 887-906.

Kelly, A. (1985). The construction of masculine science. British Fournal of Sociology of Education, 6(2), 131-154.

Kohlberg, L. (1966). A cognitive-developmental analysis of children's sex-role concepts and attitudes. In E. C. Maccoby (ed.), The development of sex differences (pp. 82-173). Stanford University Press.

Little, R. J. (1992). Regression with missing X's: A review. Fournal of the American Statistical Association, 87, 1227-1237.

Machin, S., \& Vignoles, A. (2004). Educational inequality: The widening socio-economic gap. Fiscal Studies, 25(2), 107-128.

Mujtaba, T., \& Reiss, M. J. (2013). What sort of girl wants to study physics after the age of 16? Findings from a large-scale UK survey. International Fournal of Science Education, 35(17), 2979-2998.

Nunes, T., Bryant, P., Strand, S., Hillier, J., Barros, R., \& Miller-Friedmann, J. (2017). Review of SES and science learning in formal educational settings. Education Endowment Foundation. https://royalsociety.org/ /media/policy/topics/education-skills/educa tion-research/evidence-review-eef-royalsociety-22-09-2017.pdf?la=en-GB

Piesse, A., \& Kalton, G. (2009). A strategy for handling missing data in the Longitudinal Study of Young People in England (LSYPE) (Report No. DCSF-RW086). Department for Children, Schools and Families.

Reay, D. (1998). "Always knowing" and "never being sure": Familial and institutional habituses and higher education choice. Fournal of Education Policy, 13(4), 519-529.

Reay, D., Crozier, G., \& Clayton, J. (2010). 'Fitting in' or 'standing out': Working-class students in UK higher education. British Educational Research Fournal, 36(1), 107-124.

Riegle-Crumb, C., King, B., Grodsky, E., \& Muller, C. (2012). The more things change, the more they stay the same? Prior achievement fails to explain gender inequality in entry into STEM college majors over time. American Educational Research Fournal, 49(6), 1048-1073.

Ro, H. K., Fernandez, F., \& Alcott, B. (2018). Social class, human capital, and enrollment in STEM subjects at prestigious universities: The case of England. Educational Policy, 1-28. https://doi.org/10.1177/0895904818813305 
Shanghai Ranking Consultancy. (2014). Academic ranking of world universities 2014. Shanghai Jiao Tong University. http://www.shanghairanking.com/ARWU2014.html

Singleton, A. D. (2010). The geodemographics of educational progression and their implications for widening participation in higher education. Environment and planning. 42(11), 2560-2580.

Smith, E. (2011). Women into science and engineering? Gendered participation in higher education STEM subjects. British Educational Research Fournal, 37(6), 993-1014.

Tan, E., Calabrese Barton, A., Kang, H., \& O'Neill, T. (2013). Desiring a career in STEM-related fields: How middle school girls articulate and negotiate identities-inpractice in science, Fournal of Research in Science Teaching, 50(10), 1143-1179.

Teachman, J. D. (2002). Stability across cohorts in divorce risk factors. Demography, 39(2), 331-351.

The Russell Group of Universities. (n.d.). Undergraduates from outside the EU. http s://www.russellgroup.ac.uk/for-students/undergraduate-study/students-from-out side-the-eu/

Times Higher Education. (2015). University guide 2015. http://extras.thetimes.co.uk/good universityguide/institutions/

U.S. News and World Report. (2015). Best global universities rankings. http://www. usnews.com/education/best-global-universities/rankings

Vignoles, A., \& Powdthavee, N. (2009). The socioeconomic gap in university dropouts. The B.E. Fournal of Economic Analysis \& Policy, 9(1). http://www.degruyter.com/view/ j/bejeap.2009.9.1/bejeap.2009.9.1.2051/bejeap.2009.9.1. 2051.xml

Vincent, C., Braun, A., \& Ball, S. J. (2008). Childcare, choice and social class: Caring for young children in the UK. Critical Social Policy, 28(1), 5-26.

Walker, M., \& Clark, G. (2010). Parental choice and the rural primary school: Lifestyle, locality and loyalty. Fournal of Rural Studies, 26(3), 241-249.

Walker, I., \& Zhu, Y. (2011). Differences by degree: Evidence of the net financial rates of return to undergraduate study for England and Wales. Economics of Education Review, 30, 1177-1186.

WISE Campaign. (2019). 2019 workforce statistics - 1 million women in STEM in the UK. https://www.wisecampaign.org.uk/statistics/2019-workforce-statistics-one-million -women-in-stem-in-the-uk/

WISE Campaign. (2020). Analysis of 2020 A-Level core STEM entrants - Number of core STEM A-levels completed by girls rises again. https://www.wisecampaign.org.uk/ statistics/analysis-of-2020-a-level-core-stem-entrants-number-of-core-stem-a-levels-com pleted-by-girls-rises-again/

Xie, Y., \& Shauman, K. A. (2003). Women in science. Harvard University Press.

Zwick, R. (2006). Higher education admissions testing. In R. L. Brennan (Ed.), Educational measurement (pp. 647-679). American Council on Higher Education and Praeger. 